\title{
Experimental Investigation of the Asphaltene Deposition Process during Different Production Schemes
}

\author{
M.B. Bagheri ${ }^{1}$, R. Kharrat ${ }^{2}$ and C. Ghotby ${ }^{1}$ \\ 1 Department of Petroleum and Chemical Engineering, Sharif University of Technology, Azadi St, Tehran - Iran \\ 2 Petroleum Research Center, South Khossrow St, Ghasemizadian Alley, Tehran - Iran \\ e-mail: bagheri_mb@icofc.ir - kharrał@put.ac.ir - ghotby@sharif.edu
}

\begin{abstract}
Résumé - Étude expérimentale du processus de dépôt d'asphaltènes au cours de différents modes de production - Cet article présente les résultats d'une étude de la précipitation et du dépôt d'asphaltènes qui peuvent se produire lors d'une injection de gaz pauvre, d'une injection de $\mathrm{CO}_{2}$ ou d'une déplétion naturelle en conditions de réservoir. En outre, les effets de la pression de fonctionnement, de la concentration en gaz injecté et du débit de production sur la précipitation et le dépôt d'asphaltènes ont été étudiés. Il a été constaté que l'importance du dépôt d'asphaltènes est plus prononcée dans le cas d'une injection de gaz pauvre comparativement à une injection de $\mathrm{CO}_{2}$ ou à une déplétion naturelle. Une augmentation du débit au cours d'expériences de déplétion naturelle a montré un accroissement considérable du dépôt d'asphaltènes et, en conséquence, une réduction de perméabilité au sein de la matrice poreuse. Par ailleurs, un dépôt d'asphaltènes plus important a été observé au cours des expériences d'injection de gaz lorsque la concentration molaire gazeuse dans le mélange était augmentée.
\end{abstract}

\footnotetext{
Abstract - Experimental Investigation of the Asphaltene Deposition Process during Different Production Schemes - This paper presents the results of asphaltene precipitation and deposition during lean gas injection, $\mathrm{CO}_{2}$ injection and natural depletion in reservoir conditions. In addition, the effect of variations in operating pressure, injection gas concentration and production rate on asphaltene precipitation and deposition were investigated.

The severity of asphaltene deposition was found to be more pronounced in lean gas injection in comparison with $\mathrm{CO}_{2}$ injection and natural depletion. Increasing the flow rate in natural depletion experiments showed a considerable increase in asphaltene deposition, and consequently permeability reduction in the core matrix.
}

Moreover, more asphaltene deposition was observed along the porous media in the gas injection experiments when the gas mol percent of the mixture was increased. 


\section{INTRODUCTION}

Asphaltene precipitation, flocculation and, relatively, deposition may occur at different steps from production to transporting crude oils. Several severe operational problems have been reported during production from asphaltenic oil reservoirs (Leontaritis and Mansoori, 1988; Novosad and Costain, 1990; Kabir and Jamaluddin, 1999).

Although asphaltene problems have been under research for the last 3 decades, the majority of the work in this field deals with closed systems and asphaltene precipitation (i.e. in the absence of a porous medium). The results of these works are several models that have been developed to predict asphaltene precipitation (Burke et al., 1989; Rassamdana et al., 1996; Mansoori, 1997; Andersen and Speight, 1999; Kohse et al., 2000; Nghiem et al., 2000; Hu et al., 2004). Consequently, such results are not applicable to the real production scale, where the flow as well as complex interactions between the fluid and the porous medium are always present.

Deposition on the rock surface can take place when asphaltene precipitation occurs inside the reservoir porous medium, i.e. there is no deposition of asphaltene in the porous medium before the onset of asphaltene precipitation. Precipitation and deposition are two different processes and governed by different mechanisms. When precipitation occurs, asphaltene particles come out of solution, are solidified and a new solid phase is generated in the solution, whereas when deposition takes place on the rock, this can change the wettability of the reservoir matrix, and consequently affect the flood performance (Buckley, 1998). It can also cause formation damage and wellbore plugging, requiring expensive treatment and cleanup procedures (Kamath et al., 1993; Novosad et al., 1990; Baker et al., 1992; Leontarities et al., 1992). Asphaltene deposition problems are not limited to miscible floods; they are also encountered during natural depletion, immiscible gas injection, gas-lift operations and matrix acidizing.

Many efforts in the past have been in the area of miscible flooding. Nevertheless, many questions on asphaltene properties under primary or secondary recovery conditions remain unanswered. The process of accurately describing asphaltene behavior may begin at that stage. To date, tremendous efforts have been made to describe the phenomena of asphaltene deposition (Srivastava et al., 1999; Kocabas et al., 2000; Takahashi et al., 2003; Sim et al., 2005; Papadimitriou et al., 2007) and several mathematical models have been proposed for the prediction of the rate of deposition, porosity reduction and permeability evolution (Minssieux, 1997; Ali and Islam, 1998; Wang and Civan, 2005; Garrouch et al., 2005). However, no model has been able to predict asphaltene deposition with good accuracy. Also, most models, with different degrees of rigorousness, rely on experimentally determined parameters or adjustable coefficients. In short, due to the complexity and inexactness of asphaltene properties, such problems are expected.
The main objective of this work is to experimentally investigate the effect of different production schemes on the asphaltene deposition on reservoir rocks in the reservoir conditions. In addition, it focuses on the pertinent parameters of the above schemes on the process. Injection pressure and rate as well as the ratio of injected gas to oil are the most important of these parameters. The experiments were in dynamic conditions and quantitative and qualitative experimental parameters were investigated.

\section{EXPERIMENTAL SETUP AND MATERIALS}

\subsection{Experimental Setup}

To understand the phenomenon of asphaltene deposition in reservoir conditions, several experiments were conducted within porous media. The experimental setup was designed to conduct these experiments at high pressures and high temperatures matching the reservoir conditions. The schematic of core experiments is shown in Figure 1. This facility enables experimentation in single- or multi-phase flow within porous media over a wide range of temperatures (up to $150^{\circ} \mathrm{C}$ ) and pressures (up to $48250 \mathrm{kpa}$ ).

The equipment is comprised of 12 major parts, including a heating system, fluid displacement system, vacuum pump, core holder, sampling system, two-phase gas-liquid separator, electrical balance, back pressure regulator, differential pressure transducer, hand pump, high-pressure capillary viscometer and gas accumulator.

The core holder consists of a stainless steel cylindrical body with two screw caps and an internal cylindrical rubber sleeve where the core is embedded, and can stand pressure up to $48250 \mathrm{kpa}$. More details of the equipment utilized are stated elsewhere (Bagheri, 2010).

\subsection{Experimental Materials}

In total, seven sets of experiments were performed. The oil used in these experiments was recombined oil, that is, Stock Tank Oil (STO) and separator gas originating from an oilfield in the southwest of Iran. The STO and separator gas physical properties are shown in Tables 1 and 2, respectively.

TABLE 1

Physical properties of STO used for recombining

\begin{tabular}{l|c|c}
\hline Asphaltene content & $\% w t$ & 11.50 \\
\hline Wax content & $\% \mathrm{wt}$ & 5.91 \\
\hline Viscosity @ 96 $\mathrm{C} \& 101.325 \mathrm{kPa}$ & Pa.s & 0.01 \\
\hline Specific gravity @ $15.56^{\circ} \mathrm{C} \& 101.325 \mathrm{kPa}$ & - & 0.92 \\
\hline $\mathrm{API}^{\circ} @ 101.325 \mathrm{kPa}$ & - & 22 \\
\hline
\end{tabular}




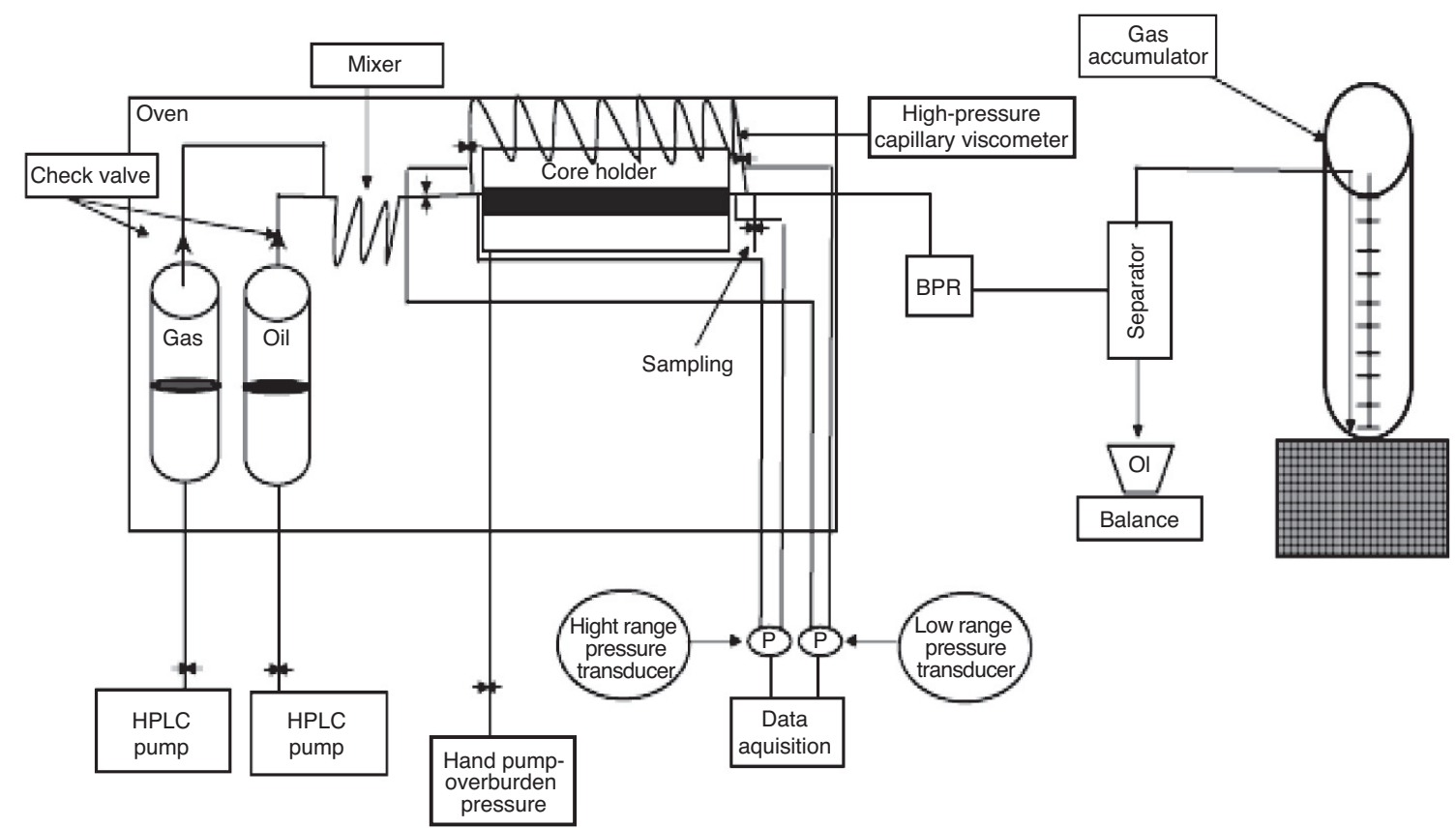

Figure 1

Schematic of core experiments.

TABLE 2

Physical properties of separator gas used for recombining

\begin{tabular}{c|c|c|c|c|c}
\hline $\begin{array}{c}\text { Pressure } \\
(\mathrm{kPa})\end{array}$ & $\begin{array}{c}\text { Gas } \\
\text { expansion } \\
\text { factor } E_{g} \\
(\mathrm{~V} / \mathrm{V})\end{array}$ & $\begin{array}{c}\text { Gas } \\
\text { volume } \\
\text { factor } B_{g} \\
(\mathrm{~V} / \mathrm{V})\end{array}$ & $\begin{array}{c}\text { Gas } \\
\text { compres. } \\
\text { factor } \\
(\mathrm{Z})\end{array}$ & $\begin{array}{c}\text { Gas } \\
\text { gravity } \\
(\text { Air }=1.0)\end{array}$ & $\begin{array}{c}\text { Gas } \\
\text { viscosity } \\
(\text { Pa.s })\end{array}$ \\
\hline 1470 & 11.69 & 0.0855 & 0.9688 & 1.0769 & $1.15 \mathrm{E}-05$ \\
\hline 101.325 & - & - & 1.0000 & 1.8269 & $9.00 \mathrm{E}-06$ \\
\hline
\end{tabular}

The reservoir fluid was recombined from dead oil and separator gas. A comparison between the recombined oil and actual reservoir fluid is given in Table 3.

The properties of the cores of each run are depicted in Table 4.

\section{EXPERIMENTAL PROCEDURES}

The major parameters measured before, during or after experiments were: fluid viscosity and density, differential pressure between the two ends of the core, effective and absolute permeability of the core, asphaltene content of the inlet and outlet fluid, and asphaltene density and porosity of the core. The procedures which were carried out in this work are as follows.
TABLE 3

Fluid composition used in experiments (mol\%)

\begin{tabular}{c|c|c|c|c}
\hline \multirow{2}{*}{ Component } & \multicolumn{4}{|c}{$\mathrm{Zi}(\%)$} \\
\cline { 2 - 5 } & $\begin{array}{c}\text { Dead } \\
\text { oil }\end{array}$ & $\begin{array}{c}\text { Separator } \\
\text { gas }\end{array}$ & $\begin{array}{c}\text { Recombined } \\
\text { fluid }\end{array}$ & $\begin{array}{c}\text { Reservoir } \\
\text { fluid }\end{array}$ \\
\hline $\mathrm{H}_{2} \mathrm{~S}$ & 0 & 0.06 & 0.03 & 0.02 \\
\hline $\mathrm{N}_{2}$ & 0 & 0.35 & 0.09 & 0.13 \\
\hline $\mathrm{CO}_{2}$ & 0 & 5.44 & 2.29 & 2.07 \\
\hline $\mathrm{C} 1$ & 0 & 44.88 & 18.88 & 17.06 \\
\hline $\mathrm{C} 2$ & 0.27 & 20.75 & 9.02 & 8.05 \\
\hline $\mathrm{C} 3$ & 1.6 & 15.49 & 7.44 & 6.88 \\
\hline IC4 & 0.68 & 2.38 & 0.39 & 1.33 \\
\hline NC4 & 3.25 & 6.34 & 7.24 & 4.43 \\
\hline IC5 & 2.75 & 1.77 & 1.59 & 2.38 \\
\hline NC5 & 3.46 & 1.68 & 2.01 & 2.79 \\
\hline FC6 & 4.91 & 0.80 & 2.85 & 3.35 \\
\hline FC7 & 4.85 & 0.05 & 2.81 & 3.03 \\
\hline FC8 & 2.57 & 0.00 & 1.49 & 1.60 \\
\hline FC9 & 1.3 & 0.00 & 0.75 & 0.81 \\
\hline FC10 & 2.69 & 0.00 & 1.56 & 1.67 \\
\hline FC11 & 4.23 & 0.00 & 2.45 & 2.62 \\
\hline C12+ & 67.44 & 0.00 & 39.11 & 41.79 \\
\hline & & & & \\
\hline
\end{tabular}


TABLE 4

Core properties used in each experiment

\begin{tabular}{|c|c|c|c|c|c|c|c|c|}
\hline \multirow{2}{*}{$\begin{array}{l}\text { Run } \\
\text { No. }\end{array}$} & \multicolumn{2}{|c|}{ Run description } & \multicolumn{2}{|c|}{ Core dimensions } & \multirow{2}{*}{$\begin{array}{c}P V \\
\left(\mathrm{~m}^{3}\right)\end{array}$} & \multirow{2}{*}{$\begin{array}{c}\phi \\
(\%)\end{array}$} & \multirow{2}{*}{$\begin{array}{l}K_{\text {eff }} \\
\left(\mathrm{m}^{2}\right)\end{array}$} & \multirow{2}{*}{$\begin{array}{l}S_{w c} \\
(\%)\end{array}$} \\
\hline & & & Length (m) & Diameter (m) & & & & \\
\hline 1 & \multirow{3}{*}{$\begin{array}{c}\text { Natural } \\
\text { depletion }\end{array}$} & $Q=1.67 \mathrm{e}-8 \mathrm{~m}^{3} / \mathrm{s}$ & 0.102 & 0.0382 & $18.9 \mathrm{e}-6$ & 16.2 & $1.01 \mathrm{e}-13$ & 25 \\
\hline 2 & & $Q=1.33 \mathrm{e}-8 \mathrm{~m}^{3} / \mathrm{s}$ & 0.1102 & 0.0382 & $20.4 \mathrm{e}-6$ & 16.2 & $9.6 \mathrm{e}-14$ & 26.3 \\
\hline 3 & & $Q=0.2 \mathrm{e}-7 \mathrm{~m}^{3} / \mathrm{s}$ & 0.1098 & 0.0382 & $20.2 \mathrm{e}-6$ & 16.1 & $8.8 \mathrm{e}-14$ & 29.2 \\
\hline 4 & \multirow{2}{*}{$\begin{array}{l}\text { Lean gas } \\
\text { injection }\end{array}$} & $50 \mathrm{~mol} \%$ gas & 0.147 & 0.0382 & $27.1 \mathrm{e}-6$ & 16.1 & 7.6e-14 & 33.8 \\
\hline 5 & & $60 \mathrm{~mol} \%$ gas & 0.149 & 0.0382 & $27.8 \mathrm{e}-6$ & 16.3 & $7.95 \mathrm{e}-14$ & 31.5 \\
\hline 6 & \multirow{2}{*}{$\begin{array}{c}\mathrm{CO}_{2} \\
\text { injection }\end{array}$} & $50 \mathrm{~mol} \% \mathrm{CO}_{2}$ & 0.111 & 0.0382 & $20.7 \mathrm{e}-6$ & 16.3 & $7.8 \mathrm{e}-14$ & 33 \\
\hline 7 & & $60 \mathrm{~mol} \% \mathrm{CO}_{2}$ & 0.111 & 0.0382 & $20.9 \mathrm{e}-6$ & 16.4 & $8.1 \mathrm{e}-14$ & 30 \\
\hline
\end{tabular}

\subsection{Preparing the Oil Sample}

To prepare the oil sample, the STO and separator gas mentioned in Table 3 were recombined based on separator conditions (Tab. 5). The recombined fluid was charged into a recombined cell and pressurized up to $28990 \mathrm{kpa}$. The cell was rotated for 2 weeks to achieve a good mixing quality.

TABLE 5

Separator conditions used for recombination

\begin{tabular}{c|c|c|c}
\hline $\begin{array}{c}\text { Pressure } \\
(\mathrm{kPa})\end{array}$ & $\begin{array}{c}\text { Temperature } \\
\left({ }^{\circ} \mathrm{C}\right)\end{array}$ & $\begin{array}{c}\text { GOR } \\
(\mathrm{Vol} / \mathrm{Vol})\end{array}$ & $\begin{array}{c}\text { Oil FVF } \\
(\mathrm{Vb} / \text { Vstock })\end{array}$ \\
\hline 101.325 & 20.4 & 43.7 & 1.28 \\
\hline
\end{tabular}

\subsection{Core Flooding Procedures}

The viscosity of the injection fluid is measured for each test. Although the viscosity of the fluid changes during the test, its change is not significant. The pressure drop along the core is measured continually and recorded by the data acquisition system every 0.5 seconds. In addition, the asphaltene content of each pore volume of injection is measured.

\subsection{Determination of Asphaltene Content}

Asphaltene content of each sample is measured by the standard IP 143 (ASTM D6560) method (Energy Institute, 2005).

\subsection{Determination of Asphaltene Density}

Accurate asphaltene density is required for calculation of core porosity after asphaltene deposition. Toluene is added to the obtained asphaltene from IP tests at different ratios. The mixture density is found at different dilution ratios and a plot of inverse solution density versus asphaltene mass fraction is obtained. Consequently, the asphaltene density can be determined indirectly from this plot by using Equations $(1,2)$ :

$$
\frac{1}{\rho_{M}}=\frac{1}{\rho_{A}}+\left(\frac{1}{\rho_{A}}-\frac{1}{\rho_{T}}\right) \times X_{A}
$$

Hence:

$$
\rho_{A}=\frac{1}{S_{0}+I}
$$

where:

$\rho_{A} \quad$ Mixture density

$\rho_{M}$ Toluene density

$\rho_{T} \quad$ Average asphaltene density

$X_{A} \quad$ Asphaltene mass fraction

$S_{0} \quad$ Slope of the inverse mixture density plot

I Intercept of the inverse mixture density plot

\section{RESULTS AND DISCUSSION}

In total, three categories of experiments were carried out. All of the experiments were performed in the presence of connate water saturation and in reservoir conditions (28 $990 \mathrm{kpa}$ and $96^{\circ} \mathrm{C}$ ). The first category of experiments simulated the natural depletion process. In these experiments, the fluid passed through the core was single-phase liquid and enabled us to calculate permeability evolution from the recorded pressure drops. These experiments were repeated at three different rates to investigate the effect of flow rate on the amount of asphaltene deposition and degree of permeability evolution. Simultaneous injection of $\mathrm{CO}_{2}$ oil and lean gas oil were, respectively, the second and third categories of experiments. The effect of the ratio of injection gas mole percent to oil on the asphaltene deposition was investigated in these experiments. Due to two-phase fluid flow through the core, the asphaltene deposition process and mechanisms were investigated based on the trend of pressure drop along the core and the amount of asphaltene obtained from IP-143 tests. 
Note that in all permeability reduction plots as well as porosity reduction plots, the ratio of instantaneous permeability to effective permeability and instantaneous porosity to initial porosity of the core was plotted versus pore volume of injected fluid. In the following, the findings from the experiments performed are reported.

\subsection{Recombined Oil Injection at Different Pressures (Simulation of Natural Depletion Scheme)}

The main objective of this experiment was to investigate asphaltene deposition and its pertinent permeability evolution due to the pressure depletion process in reservoir conditions. The experiment involved reservoir oil. In this experiment 19 pore volumes of oil were injected at $96^{\circ} \mathrm{C}$ and the core pressure was reduced in 6 steps from 28990 to $10350 \mathrm{kPa}$ using BPR. The pressure steps were: 28990, 24850, 20700 , 17255,13805 and $10350 \mathrm{kPa}$. During this experiment the flow rate was about $1.67 \mathrm{e}-8 \mathrm{~m}^{3}$ per second. Figure 2 shows the pressure steps of the experiment and recorded $\Delta P$ between the two ends of the core. The sharp increase in pressure drop ( $900 \mathrm{kPa}$ ) by the end of the production period is an indication of asphaltene deposition.

\subsubsection{Calculations}

\section{Permeability Calculations}

During this experiment permeability was calculated from the measured pressure drop along the core through Darcy's law (Eq.3):

$$
q=0.9864 \frac{k A}{\mu} \frac{\Delta P}{L}
$$

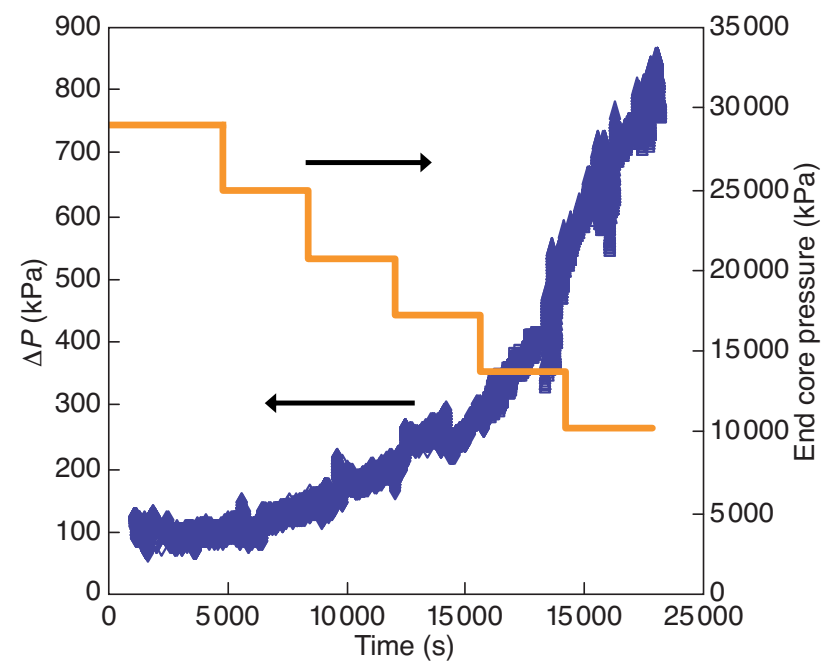

Figure 2

Recorded $\Delta P$ between the 2 ends of the core and pressure steps (natural depletion test $Q=1.67 \mathrm{e}-8 \mathrm{~m}^{3} / \mathrm{s}$ ).

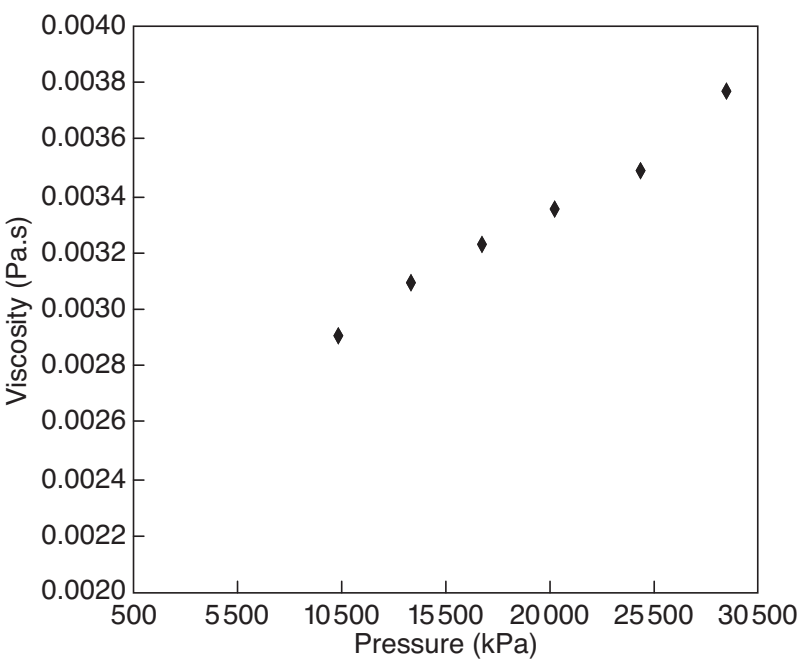

Figure 3

Recombined oil viscosity at different pressures and $96^{\circ} \mathrm{C}$.

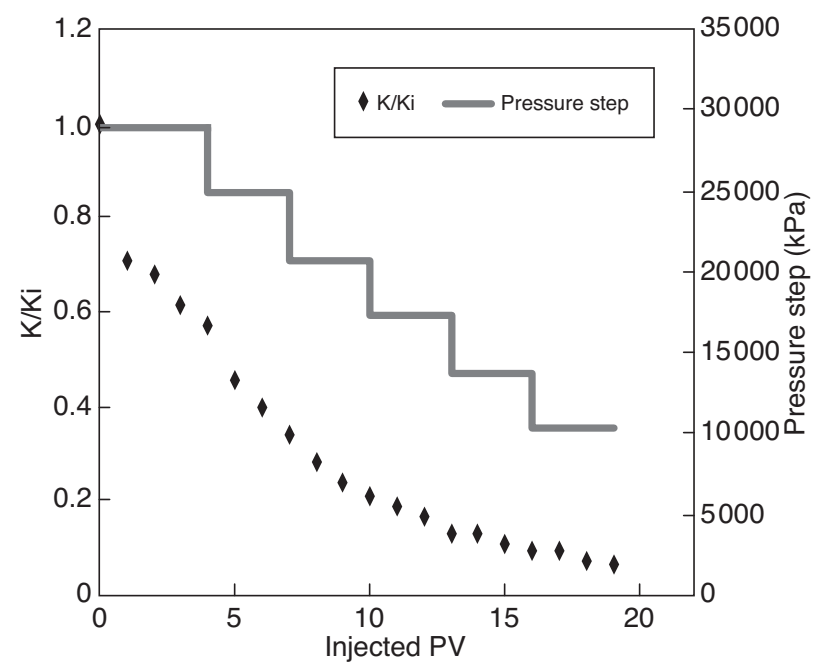

Figure 4

Permeability reduction and pressure steps (natural depletion test $Q=1.67 \mathrm{e}-8 \mathrm{~m}^{3} / \mathrm{s}$ ).

In the above equation, $q$ is the injection flow rate, which is expressed in $\mathrm{cm}^{3} / \mathrm{s}, A$ is the cross-sectional area of the porous medium in $\mathrm{cm}^{2}, L$ is the length of the porous medium in $\mathrm{cm}$, $\Delta P$ is the pressure differential in bar, $\mu$ is the viscosity of the fluid in $\mathrm{cp}$, and $k$ represents the permeability of the porous medium, which is expressed in darcies. Fluid viscosity was obtained before each pressure step through the high pressure viscometer. The obtained viscosities are depicted in Figure 3. A reduction in viscosity is observed with a decrease in pressure as expected, due to asphaltene deposition.

Based on the pressure and viscosity data, the permeability is calculated from Equation (3) (Fig. 4). Since permeability is a function of $\Delta P$, as can be seen in Figure 4 permeability 
along the core decreased as the pressure decreased (solid line). This confirms the occurrence of asphaltene deposition during the natural depletion scheme.

\section{Porosity Calculations}

The required parameters to calculate the core porosity after each pore volume of injection are: mass percent of deposited asphaltene, asphaltene density and recombined oil density. The following equation was employed in order to calculate the core porosity after each pore volume of injection:

$\varnothing=$ PV $/$ Bulk vol

$\mathrm{PV}=$ Original $\mathrm{PV}-$ Deposited asphaltene vol

Deposited asphaltene vol $=$

Deposited asphaltene mass / Asphaltene density

Deposited asphaltene mass $=$

Original asphaltene mass - Asphaltene mass in output fluid

Asphaltene mass in output fluid $=$

Asphaltene content $\times$ oil mass / 100

The outlet asphaltene concentration is obtained from the IP-143 test which was carried out and its density was measured according to the method mentioned in Section 2.4 (Fig. 5). The recombined oil bubble point was measured from the CCE test and its density at different pressures above the saturation pressure was measured using a differential vaporization test at $96^{\circ} \mathrm{C}(\mathrm{Tab} .6)$.

\section{TABLE 6}

Recombined oil density measured using a differential vaporization test at $96^{\circ} \mathrm{C}$

\begin{tabular}{c|c}
\hline Pressure $(\mathrm{kPa})$ & Oil density $\left(\mathrm{kg} / \mathrm{m}^{3}\right)$ \\
\hline 28989 & 733.6 \\
\hline 24848 & 732.2 \\
\hline 20707 & 730.8 \\
\hline 17256 & 729.5 \\
\hline 13804 & 728.1 \\
\hline 10353 & 726.7 \\
\hline
\end{tabular}

Saturation pressure $=7316 \mathrm{kPa}$

The asphaltene weight percent of the outlet fluid and ratio of instantaneous core porosity to initial porosity are shown in Figure 6. It is clear from this figure that porosity reduction is a function of the amount of asphaltene deposition. Moreover, it can be seen from the asphaltene wt $\%$ curve that the amount of asphaltene deposition in primary pore volumes is almost more than in last pore volumes. Based on this observation, it can be concluded that asphaltene particles preferentially deposit on clean surfaces rather than surfaces covered by asphaltene.

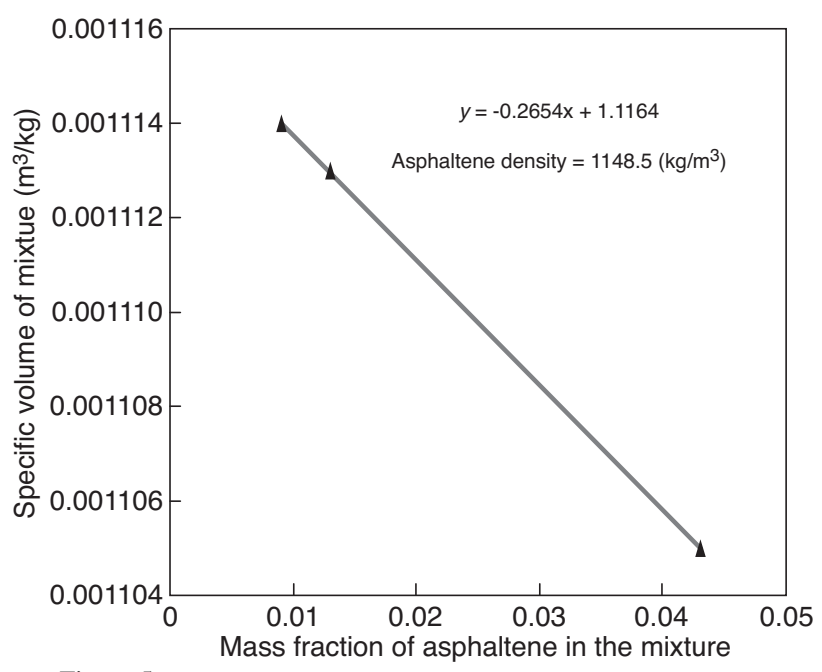

Figure 5

Calculation of asphaltene density.

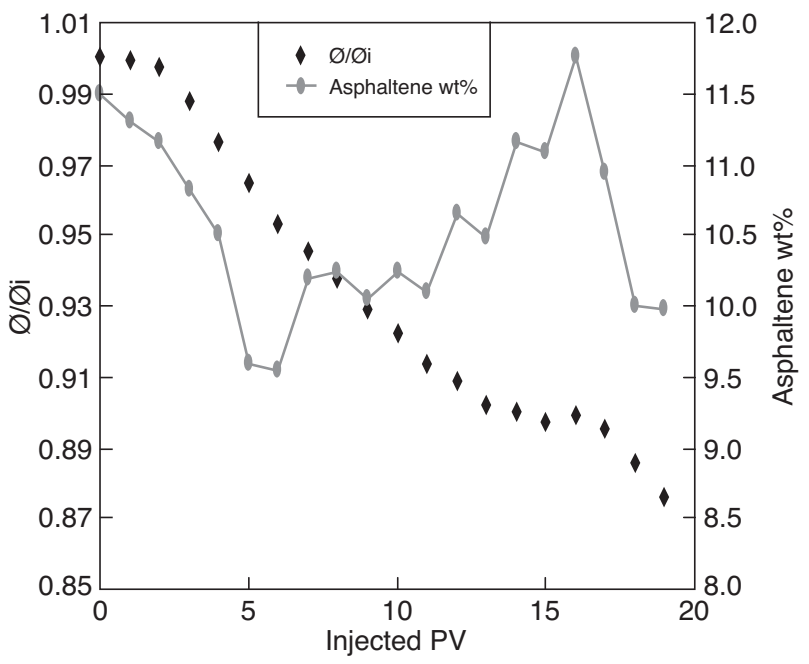

Figure 6

Change in asphaltene weight percent and ratio of instantaneous porosity to initial porosity (natural depletion $Q=1.67 \mathrm{e}-8 \mathrm{~m} 3 / \mathrm{s}$ ).

As is obvious in Figures 4 and 6, the core permeability and asphaltene wt $\%$ decreased after one pore volume of injection at $28990 \mathrm{kPa}$. This shows that the current reservoir pressure is lower than its asphaltene onset pressure. One of the most important findings from this experiment is the drastic permeability reduction in the core (about 30 percent) by the beginning of the injection, which shows the plugging or narrowing of the pore throats immediately after asphaltene deposition. Another major observation refers to the sudden reduction in permeability and asphaltene wt $\%$ at the 5 th pore volume of injection. By following the injection, the permeability reduction decrease shows that the tendency of asphaltene deposition on the pore surfaces that are covered by asphaltene is less than on the clean surfaces. These phenomena 
can be observed by changing the fluid flow rate that passes through the core, as will be described in the next section.

\subsubsection{Effect of Flow Rate on the Asphaltene Deposition Process}

To investigate the effect of the injection rate (the rate that fluid passes through the porous media), the test was repeated twice at different injection rates $\left(1.33 \mathrm{e}-8\right.$ and $\left.0.2 \mathrm{e}-7 \mathrm{~m}^{3} / \mathrm{s}\right)$. Figures 7 through 9 show the results and comparison of natural depletion experiments at three different rates. As is obvious in these figures, an increase in the flow rate is followed by an increase in asphaltene deposition, porosity reduction and permeability impairment, which is due to more pressure drop along the core. Since these core experiments simulate the distances far from the well, it can be concluded that increasing the production rate from the wells causes more serious formation damage problems far from the well. Note that the current experiments were carried out above the saturation pressure and if the experiments continued until bubble point pressure this conclusion might change. It should be noted that the reduction in the porosity ratio for all tests is much lower than the reduction in the permeability ratio. This may show that the deposition process occurred at local positions in the core rather than along the core.

\subsection{Simultaneous Injection of Recombined Oil and Associated Gas (Simulation of Lean Gas Injection)}

Two core flood experiments were conducted to assess the asphaltene deposition during lean gas injection. The effect of changes in the mole percent of injected gas on asphaltene

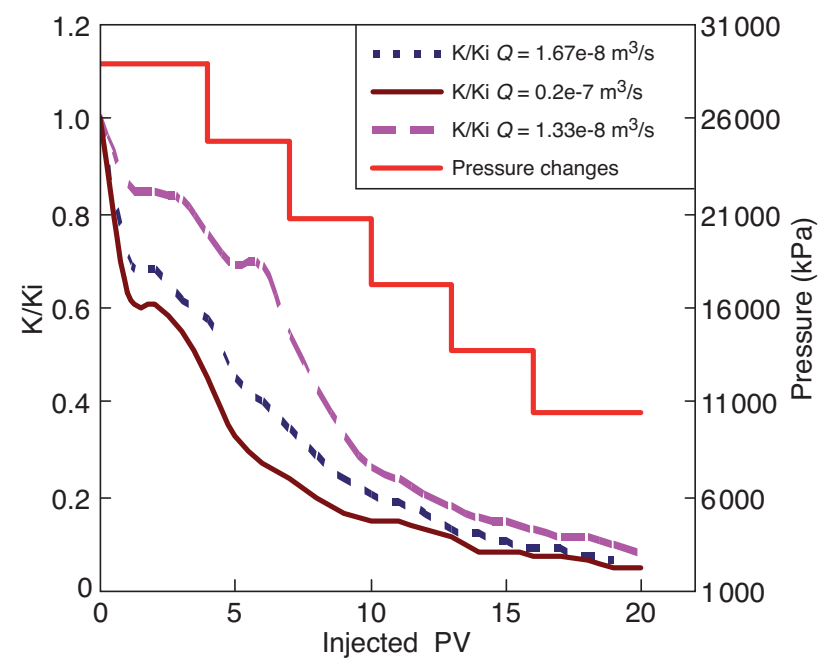

Figure 7

$K / K_{i}$ and pressure changes during the test (natural depletion experiments).

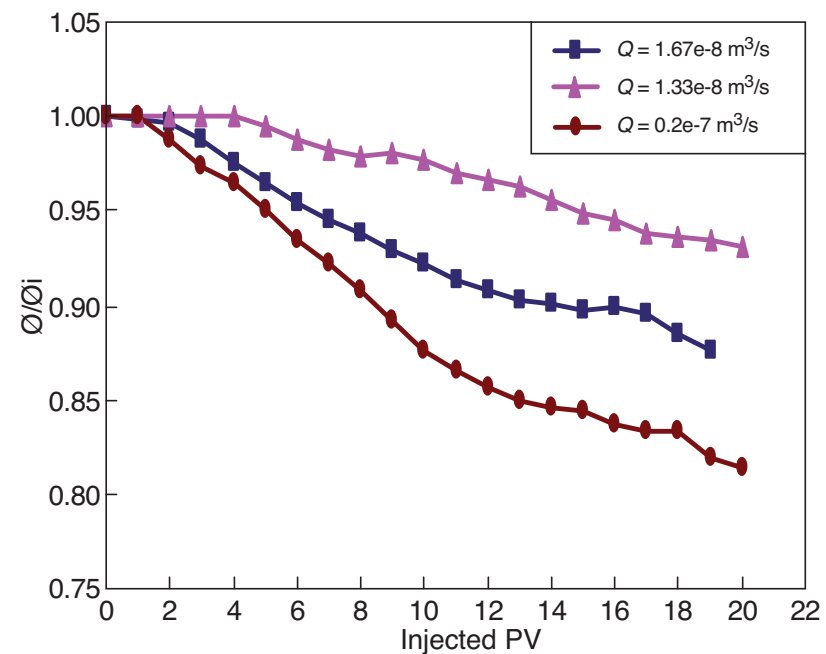

Figure 8

Ratio of instantaneous porosity to initial porosity (natural depletion experiments).

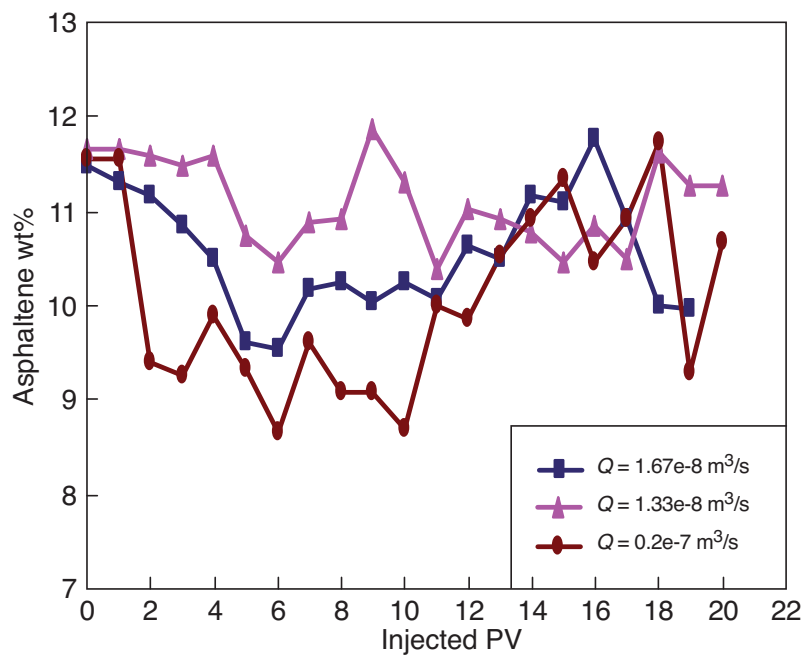

Figure 9

Asphaltene wt $\%$ of outlet fluid (natural depletion experiments).

deposition was investigated. The first test was carried out with a mixture containing 50 mole percent of gas, and the second test with a mixture containing 60 mole percent of gas. In these tests 5 and 4 pore volumes of mixture were injected into the core, respectively, in the first and second tests, and the flow rate was $1.67 \mathrm{e}-8 \mathrm{~m}^{3} / \mathrm{s}$ during both experiments. During the experiments, both fluids (recombined oil and injection gas) were injected at $28990 \mathrm{kPa}$ and $96^{\circ} \mathrm{C}$. Note that a single-phase condition was not achieved for the mixture that was injected into the core; therefore, a severe pressure fluctuation along the core was observed. It can be seen from Figure 10 that increasing the mole percent of injected 


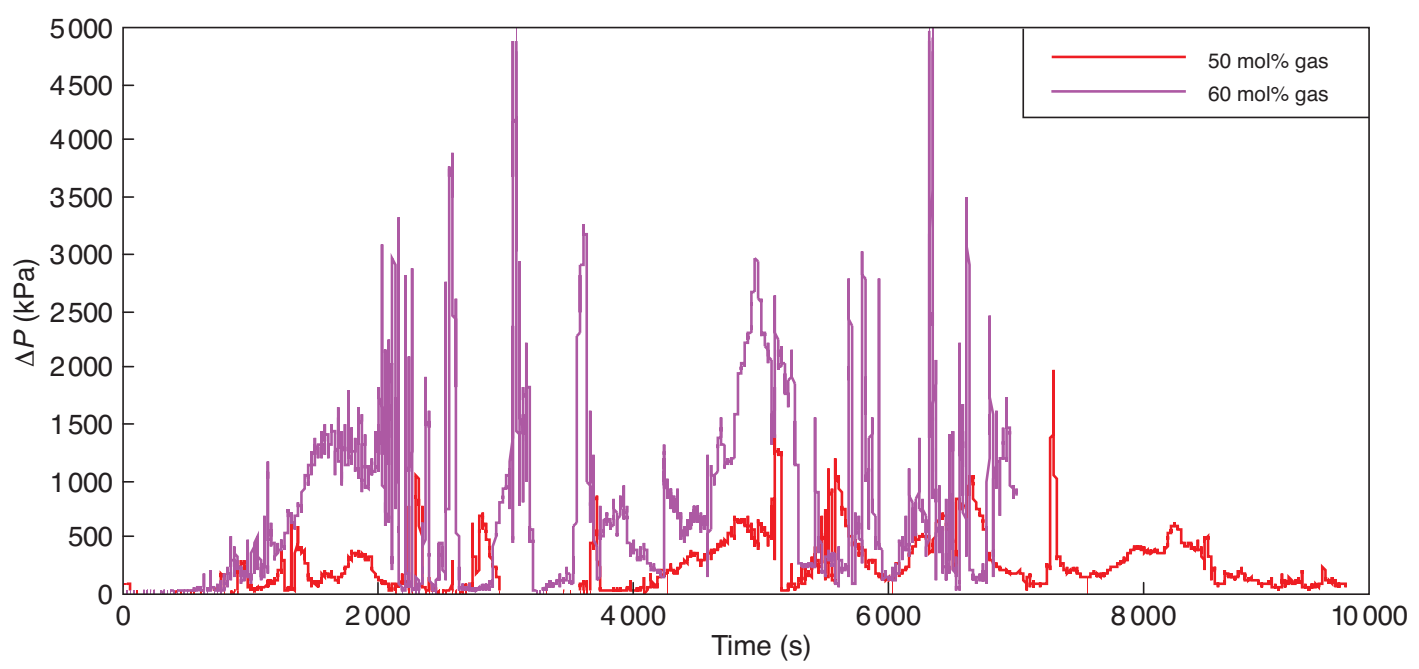

Figure 10

Pressure differences along the core in lean gas injection tests.

gas causes more pressure drop along the core, which means more asphaltene deposition within the porous media.

\section{Calculations}

Since single-phase fluid flow through the core was not achieved in these sets of experiments, Equation (3) cannot be applied to calculate the permeability. Thus, the degree of asphaltene deposition was investigated based on porosity calculation.

In addition to the required parameters which are mentioned in Section 3.1.1 for porosity calculation, the injection gas density is also needed. For this purpose, the gas density is calculated from Equation (5):

$$
\rho_{g}=\frac{P M_{a}}{z R T}
$$

in which:

$$
M_{a}=\sum_{i=1}^{n} y_{i} M_{i}
$$

where:

$\rho_{g} \quad$ Gas density $\left(\mathrm{lb} / \mathrm{ft}^{3}\right)$

$P \quad$ Pressure (psi)

$M_{a}$ Apparent molecular weight of a gas mixture

Z Gas compressibility factor

$R \quad$ Universal gas constant

$T$ Temperature $\left({ }^{\circ} \mathrm{R}\right)$

$y_{i} \quad$ Mole fraction of component $i$ in the mixture

$M_{i} \quad$ Molecular weight of the $i$ th component in the mixture

The gas compressibility factor is obtained from Standing and Katz's compressibility factors chart (Standing and Katz,
1942) based on the pseudo-critical pressure and temperature of the mixture. The oil mass and porosity are calculated, respectively, from Equations (5) and (7):

Oil mass $=$ PV $(1-$ Gas vol fraction $)$

Gas vol fraction $=\mathrm{Gas}$ vol $/(\mathrm{Gas}$ vol + Oil vol $)$

$\mathrm{Gas}$ vol $=\mathrm{Gas}$ mol $\% \times$ Gas molar vol

Gas molar vol $=$ Gas density $/$ Gas molecular weight

Oil vol $=$ Oil $\mathrm{mol} \% \times$ Oil molar vol

Oil molar vol = Oil density / Oil molecular weight

The recombined oil density in $28990 \mathrm{kPa}$ was used from Table 6 and the asphaltene density was measured based on the procedure described in Section $2.4\left(1160 \mathrm{~kg} / \mathrm{m}^{3}\right)$. The asphaltene weight percent of the outlet fluid and ratio of instantaneous core porosity to initial porosity for both tests are shown in Figure 11.

The amount of porosity reduction after 4 pore volumes of injection confirms the results obtained from Figure 10 that asphaltene deposition at higher gas mole percent is more significant. Another major observation from this curve refers to the increase in the asphaltene wt $\%$ at the 5 th pore volume of injection. This observation confirms that perhaps the asphaltene entrainment mechanism takes place under certain conditions depending on the fluid and rock properties.

Figure 12 depicts the images of the core sections after the lean gas injection experiment with 60 mole $\%$ gas. After the test, the core was flooded by Cyclohexane at a low rate $\left(1.67 \mathrm{e}-9 \mathrm{~m}^{3} / \mathrm{s}\right)$ to remove the reduced oil saturation in the core. Note that Cyclohexane neither causes asphaltene precipitation nor dissolves the deposited asphaltene. The figure illustrates the core cross-sections at five locations sequentially along the length, starting from the inlet end. The first 


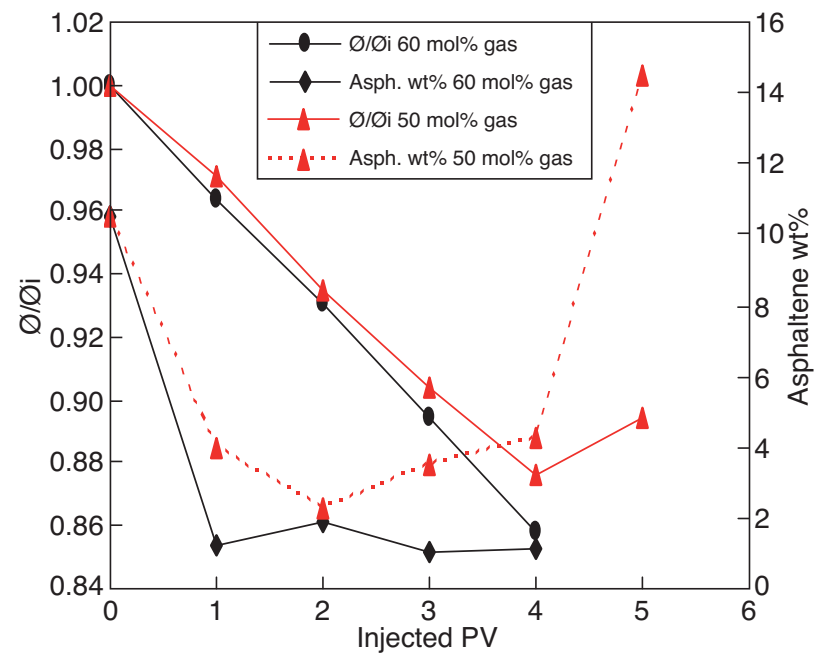

Figure 11

Asphaltene wt $\%$ of the outlet fluid and ratio of instantaneous porosity to initial porosity at the end of each pore volume of injection (lean gas injection tests).

image on the left represents a location approximately 0.005 meters from the inlet and each subsequent image from left to right portrays scan locations 0.035 meters apart. The last image located on the right depicts the scan closest to the outlet.

As is obvious from Figure 12, the accumulation of deposited asphaltene is at localized areas in the core crosssection and decreases along the core.

\subsection{Simultaneous Injection of Recombined Oil and $\mathrm{CO}_{2}$ (Simulation of $\mathrm{CO}_{2}$ Injection)}

In these experiments the effect of the mole percent of $\mathrm{CO}_{2}$ in the mixture was investigated. The oil used in these experiments was recombined oil, described in Table 3. During the first test, $\mathrm{CO}_{2}$ and recombined oil were injected into the core at a rate of $3.5 \mathrm{e}-9$ and $1.32 \mathrm{e}-8 \mathrm{~m}^{3} / \mathrm{s}$, respectively $(50 \mathrm{~mol} \%$ $\mathrm{CO}_{2}$ ). After approximately five pore volumes of throughput, no significant increase in pressure drop was observed across the core, indicating that the amount of asphaltene trapped in the core was relatively small and did not significantly affect the permeability of the core. The second test was conducted with a mixture containing $60 \mathrm{~mol} \%$ of $\mathrm{CO}_{2}$. In this test, $\mathrm{CO}_{2}$ and recombined oil were injected into the core at a rate of $4.83 \mathrm{e}-9$ and $1.18 \mathrm{e}-8 \mathrm{~m}^{3} / \mathrm{s}$, respectively. When the mixture was flowed through the core, a slight increase in pressure drop across the core sample was observed at the end of two pore volumes of mixture throughput (about $0.4 \mathrm{e}-4 \mathrm{~m}^{3}$ ). By continuing the injection, a significant increase in pressure drop across the core sample was observed at the end of the 5th pore volume of mixture throughput (about $0.0001 \mathrm{~m}^{3}$ ), indicating that the amount of asphaltene deposited in the core was more than in the previous test and the core permeability was affected. Figure 13 shows the pressure drop across the cores in both tests. As is shown in this curve, pressure drop along the core in the first experiment $\left(50 \mathrm{~mol} \% \mathrm{CO}_{2}\right)$ was constant and no significant change was observed.

These observations agreed with results from effluent oil analysis in both tests, showing that the asphaltene content of the produced oil in the first test is not significantly smaller than its original value, whereas in the second test, the asphaltene content of the produced oil is much smaller than the original oil asphaltene content (Fig. 14).

\section{Calculations}

Since single-phase liquid was not achieved in these tests, Equation (3) cannot be applied for permeability calculations; therefore, the degree of asphaltene deposition was discovered based on porosity change during the injection. The injection gas $\left(\mathrm{CO}_{2}\right)$ density is calculated from Equation (4) and the gas compressibility factor is obtained from Standing and Katz's compressibility factors chart. The asphaltene density is calculated based on the method described in Section 3.1.1 $\left(1150 \mathrm{~kg} / \mathrm{m}^{3}\right)$ and the recombined oil density in $28990 \mathrm{kPa}$ is used from Table 6 . Finally, the oil mass and porosity are calculated, respectively, from Equations (5) and (7). Figure 15 shows the ratio of instantaneous porosity to its initial value at the end of each pore volume of mixture throughput. As is obvious from this curve, the amount of reduction in the ratio

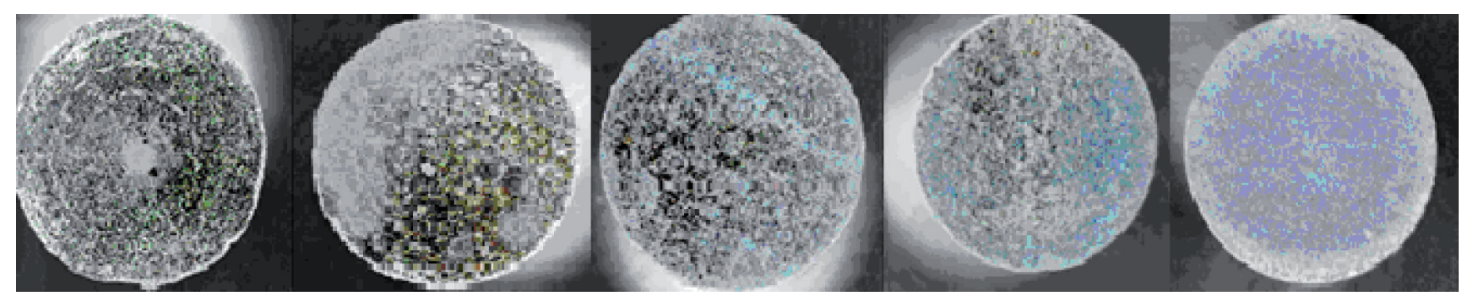

Figure 12

Cross-sections of the core sample after the lean gas injection experiment (60 mol\% gas). 


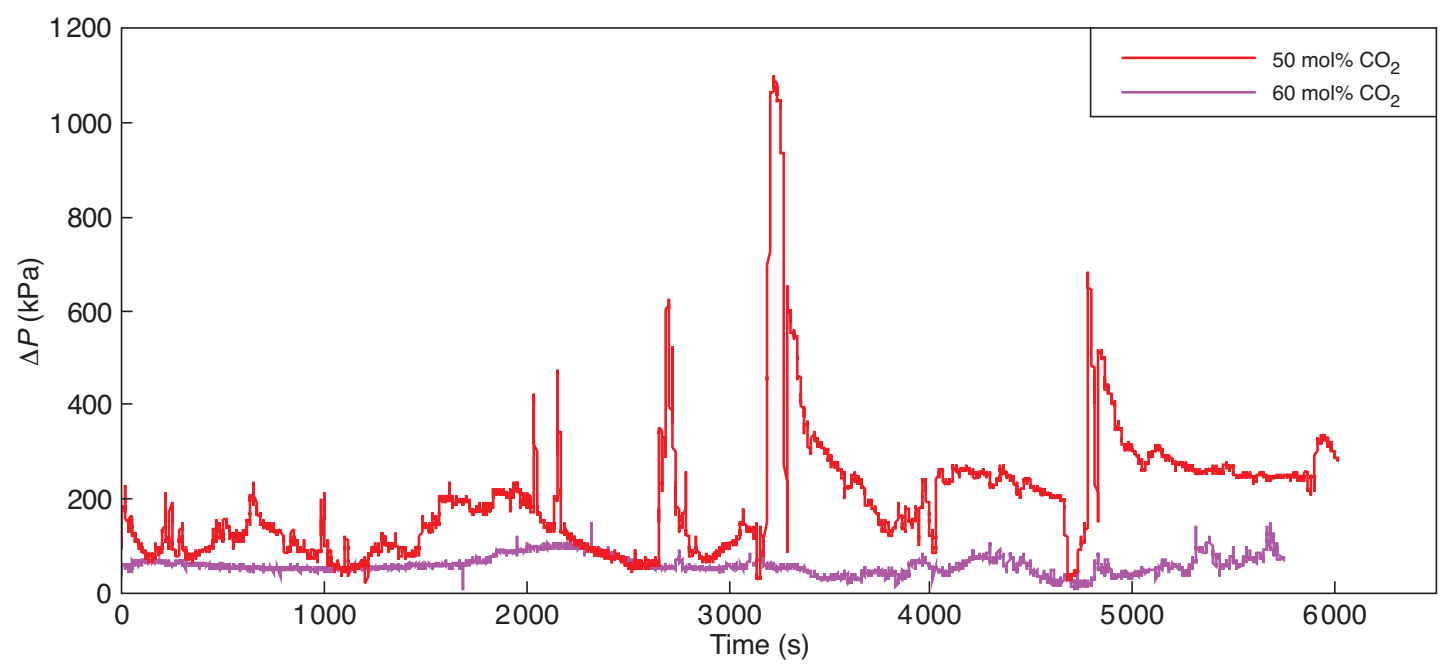

Figure 13

Pressure differences along the core in $\mathrm{CO}_{2}$ injection tests.

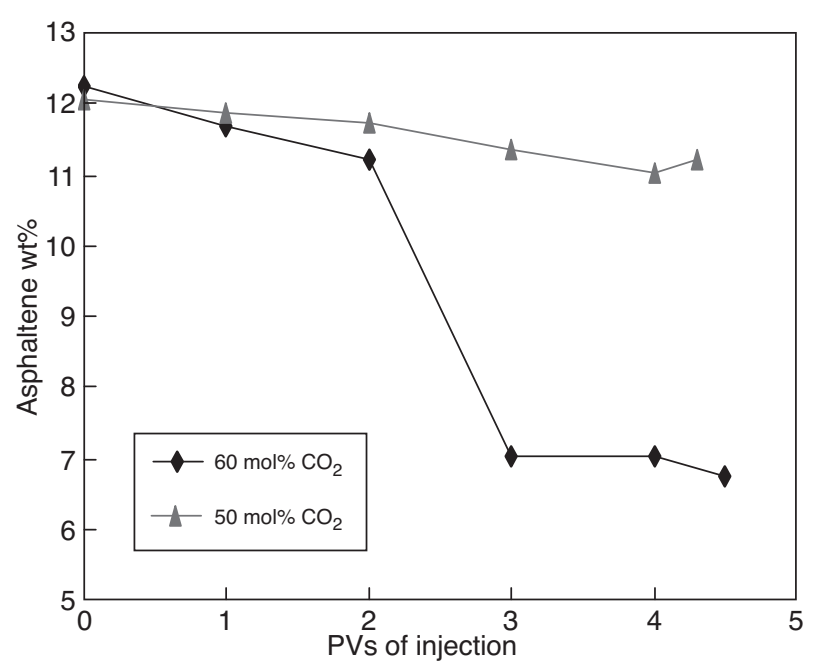

Figure 14

Asphaltene wt $\%$ of outlet fluid at the end of each pore volume of injection $\left(\mathrm{CO}_{2}\right.$ injection tests).

of instantaneous porosity to initial porosity after about 4.5 pore volumes of injection is about 1.5 and 8 percent, respectively, in the first test $\left(50 \mathrm{~mol} \% \mathrm{CO}_{2}\right)$ and second test $\left(60 \mathrm{~mol} \% \mathrm{CO}_{2}\right)$. These values confirm that, at a higher mole percent ratio of $\mathrm{CO}_{2}$ to oil, the asphaltene deposition problem is more significant.

\subsection{Comparison of Experiments Performed}

In order to compare the effect of different production mechanisms on the asphaltene deposition process, the porosity evolution of the experiments performed can be compared with each other (Fig. 8,11 and 15). Since these tests (4 primary pore volumes of each test) were carried out at the same pressure $(\mathrm{BPR}=28990 \mathrm{kPa})$ and temperature $\left(96^{\circ} \mathrm{C}\right)$, the changes in trend of porosity evolution are pertinent to the mixture composition that was injected through the core. As is obvious, the most serious problem with asphaltene deposition took place in the lean gas injection experiments in which asphaltene deposition decreases with a decrease in the mole percent of injection gas in the injected mixture. On the other hand, there is a minor asphaltene deposition problem in the natural depletion experiment with $Q=1.33 \mathrm{e}-8 \mathrm{~m}^{3} / \mathrm{s}$. Another major observation from this curve is that the porosity reduction in the $\mathrm{CO}_{2}$ injection test with $50 \mathrm{~mol} \% \mathrm{CO}_{2}$ after 4 pore volumes of injection is less than the natural depletion tests with $Q=1.67 \mathrm{e}-8$ and $0.2 \mathrm{e}-7 \mathrm{~m}^{3} / \mathrm{s}$, whereas the same value for the $\mathrm{CO}_{2}$ injection test with $60 \mathrm{~mol} \% \mathrm{CO}_{2}$ is greater than the natural depletion tests.

\section{COMPARISON OF EXPERIMENTAL RESULTS WITH DEVELOPED MODELS}

The objective of this section is to compare the match quality between two major previous models developed by Minssieux et al. (1997) and Wang et al. (2005) with the generated experimental data in this work. Details of these models are described elsewhere (Bagheri, 2010).

\subsection{Minssieux et al.'s Model}

Three possible mechanisms, surface deposition, pore bridging and formation of filtration cake, may occur during asphaltene deposition in porous media (Wojtanowicz et al., 1987; Minssieux et al., 1998). Solver was applied to perform curve fitting and investigate the dominant process during natural depletion $\left(Q=1.67 \mathrm{e}-8 \mathrm{~m}^{3} / \mathrm{s}\right)$ in the core. Figure 16 depicts the measured permeability data and the prediction from each 


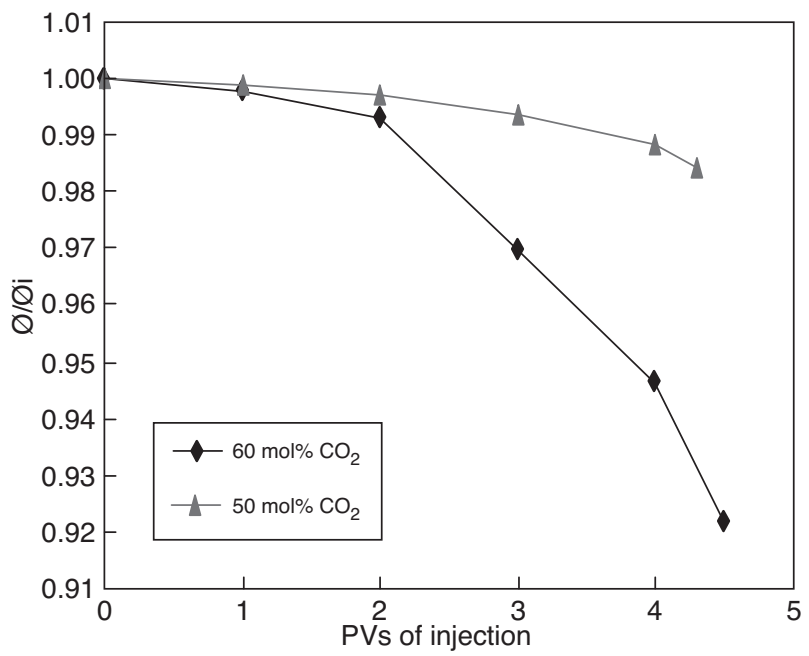

Figure 15

Ratio of instantaneous porosity to initial porosity at the end of each pore volume of injection $\left(\mathrm{CO}_{2}\right.$ injection tests).

model. These models were not able to predict the amount of permeability reduction with acceptable deviation. Hence, filter cake formation is probably the prevailing mechanism. Table 7 presents the results of the optimization by Solver and values of model parameters.

\subsection{Wang et al.'s Model}

Wang et al. introduced a model that performs the simultaneous deposition of paraffin and asphaltene in a core test by modi-
TABLE 7

Results of nonlinear regression by Solver for deposition models

\begin{tabular}{c|c|c|c}
\hline $\begin{array}{c}\text { Deposition } \\
\text { mechanism }\end{array}$ & $\begin{array}{c}\text { Model } \\
\text { equation }\end{array}$ & $\begin{array}{c}\text { Fitted parameter, } \\
\mathrm{A}, \mathrm{B}, \mathrm{C}\left(\frac{1}{\mathrm{~min}}\right)\end{array}$ & $\begin{array}{c}\text { Sum } \\
\text { of the squared } \\
\text { of residuals }\end{array}$ \\
\hline $\begin{array}{c}\text { Formation of } \\
\text { filtration cake }\end{array}$ & $\frac{K}{K_{0}}=\frac{1}{1+C . t}$ & 0.018462368 & 0.062763626 \\
\hline $\begin{array}{c}\text { Surface } \\
\text { deposition }\end{array}$ & $\sqrt{\frac{K}{K_{0}}}=1-A_{0} t$ & 0.002753023 & 0.180556255 \\
\hline $\begin{array}{c}\text { Pore } \\
\text { bridging }\end{array}$ & $\frac{K}{K_{0}}=1-B . t$ & 0.0021 & 1.558247885 \\
\hline
\end{tabular}

fying the Civan model (Civan, 1995). Wang et al.'s model developed one-dimensional, three-phase models with four pseudo-components for paraffin and asphaltene to simulate the transport of paraffin and asphaltene precipitates in porous media. The deposition model includes static and dynamic pore surface deposition and pore throat plugging of the paraffin and asphaltene. Equations (8) through (10) present this model:

$$
\begin{gathered}
\frac{\partial E_{a}}{\partial t}=\alpha^{\prime} C_{a} \phi-\beta^{\prime} E_{a}\left(v_{l}-v_{c r, l}\right)+\gamma^{\prime} u_{l} C_{a} \\
\phi=\phi_{i}-E_{a} \\
k=f_{p} k_{i}\left(\frac{\phi}{\phi_{i}}\right)^{n}
\end{gathered}
$$

where $E_{a}$ is the volume fraction of the deposited asphaltene per bulk volume of the porous media, $t$ is time, $v$ is the interstitial velocity of the liquid phase, $u_{l}$ is the velocity of the liquid

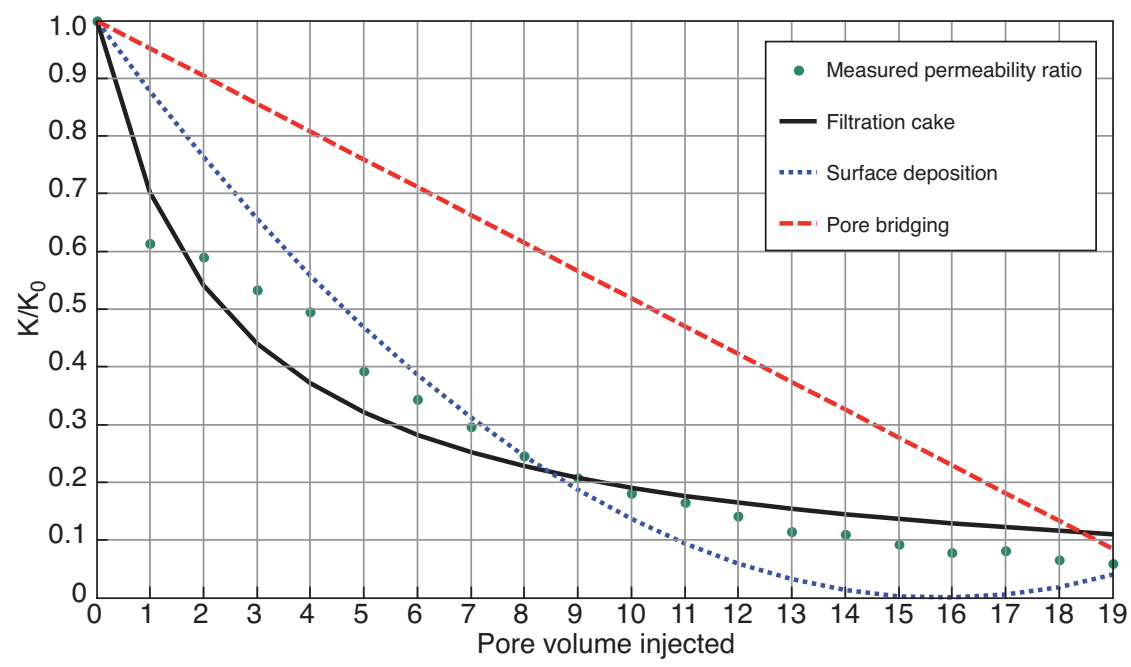

Figure 16

Comparison between measured permeability data and Minssieux et al.'s models. 


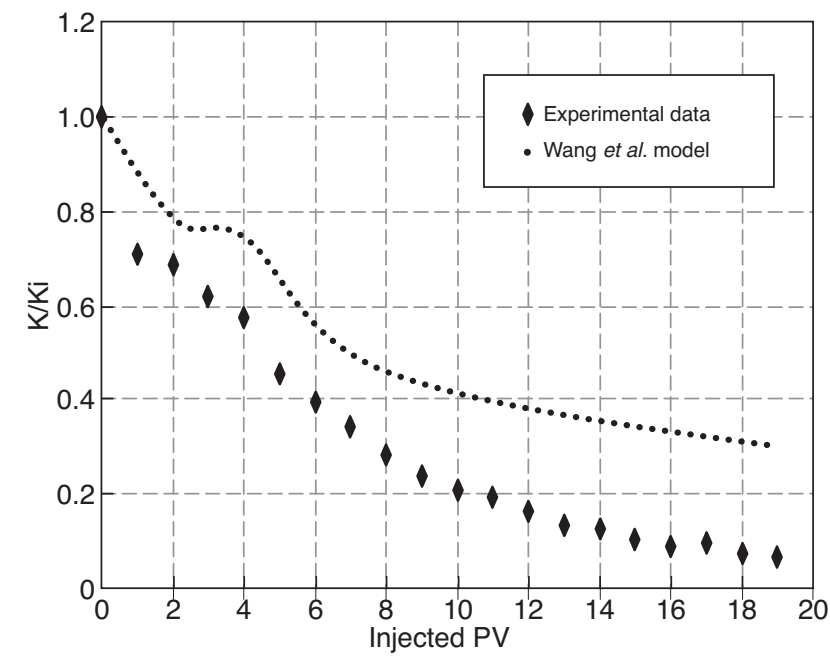

Figure 17

Comparison between measured permeability data and Wang et al.'s model.

phase and $\gamma$ is the plugging deposition rate coefficient. Note that " $n$ " in Equation (11) is bounded between 3 and 7 in this model.

Figure 17 shows the match quality of Wang et al.'s model with the generated experimental data and as it illustrates, the match is poor. The main parameters which should be investigated more in this model are the adjustable parameters (especially exponent $n$ ) and the eliminated parameters such as asphaltene saturation.

\section{CONCLUSIONS}

This experimental study was undertaken to investigate the effect of different parameters on the asphaltene deposition process. The study covered natural depletion, $\mathrm{CO}_{2}$ injection and lean gas injection in consolidated sandstone formations using recombined oil. The following conclusions were drawn from this work:

- because of more pressure drop along the media, an increase in the flow rate is accompanied by an increase in asphaltene deposition, and consequently an increase in formation damage far from the wells above bubble point pressure;

- in the case of gas injection experiments, the most important factor on which the asphaltene precipitation/deposition depends is the $\mathrm{CO}_{2}$ or injection gas concentration. The asphaltene concentrations determined from IP 143 tests reveal that more gas mole percent in the mixture is associated with more asphaltene deposition;

- the inclusion of porosity calculation for the characterization of core samples, despite its simplicity, has given very useful results, providing valuable insight into the deposition mechanism. It provides useful information about the parameters that affect the extent of formation damage;

- although asphaltene deposition is observed in all of the examined fluid combinations, with the lean gas injection it was more pronounced.

\section{ACKNOWLEDGMENT}

The authors would like to acknowledge the Petroleum Engineering and Development Company (PEDEC) for their financial support. Special thanks go to M. Khalili and A. Mirzabozorg for providing technical assistance in core flooding experiments and T. Pak for her involvement in asphaltene content determination tests. In addition, the authors would like to acknowledge the technical and scientific assistance and helpful discussions with Dr M.H. Ghazanfari (Petroleum Research Center, Tehran), and Z. Dastkhan (National Iranian South Oil Company, Ahwaz).

\section{REFERENCES}

Ali M.A., Islam M.R. (1998) The Effect of Asphaltene Precipitation on Carbonate-Rock Permeability: An Experimental and Numerical Approach, SPE Prod. Facil. 178-183.

Andersen S.I., Speight J.G. (1999) Thermodynamic models for asphaltene solubility and precipitation, J. Petrol. Sci. Eng. 22, 53-66.

Bagheri M.B. (2010) Experimental study and mathematical modeling of asphaltene deposition in porous media, $P h D$ Dissertation, Sharif University of Technology, Tehran.

Baker H.L. (1992) Asphaltene Deposition Control Using Chemical Control Agents, CIM Annual Technical Conference, Calgary, June 7-10.

Buckley J.S. (1998) Wetting Alternation of Solid Surfaces by Crude Oils and their Asphaltenes, Oil Gas Sci. Technol. - Rev. IFP 53, 3 , 303-312.

Burke N.E., Hobbs R.D., Kashou S.F. (1989) Measurement and modeling of asphaltene precipitation from live reservoir fluid systems, 63rd SPE Annual Technical Conference and Exhibition, Houston, USA, October 2-6.

Civan F. (1995) Modeling and Simulation of Formation Damage By Organic Deposition, Presented at the First International Symposium in Colloid Chemistry in Oil Production: Asphaltenes and Wax Deposition, JSCOP'95, Rio de Janeiro- Ri- Brazil, November 2629, pp. 102-107.

Energy Institute (2005) IP Standard Test Methods for Analysis and Testing of Petroleum and Related Products, London, UK.

Garrouch A.A., Al-Ruhaimani, Feras A. (2005) Simple Models for Permeability Impairment in Reservoir Rocks Caused by Asphaltene Deposition, Petrol. Sci. Technol. 23, 7-8, 811-826.

$\mathrm{Hu}$ Y.F., Li S., Liu N., Chu Y.P., Park S.J., Mansoori G.A., Guo T.M. (2004) Measurement and corresponding states modeling of asphaltene precipitation in Jilin reservoir oils, J. Petrol. Sci. Eng. 41, 169-182.

Kabir C.S., Jamaluddin A.K.M. (1999) Asphaltene Characterization and Mitigation in South Kuwait's Marrat Reservoir, SPE Middle East Oil Show, Bahrain, February 20-23. 
Kamath V.A., Yang J., Sharma G.D. (1993) Effect of Asphaltene Deposition on Dynamic Displacements of Oil by Water, SPE Western Regional Meeting, Anchorage, May 26-28.

Kocabas I., Islam M.R., Modarress H. (2000) A wellbore model for field-scale modeling of asphaltene plugging, J. Petrol. Sci. Eng. 26, 19-30.

Kohse B.F., Nghiem L.X., Maeda H., Ohno K. (2000) Modeling phase behavior including the effect of pressure and temperature on asphaltene precipitation, SPE Asia Pacific Oil and Gas Conference and Exhibition, Brisbane, Australia, October 16-18.

Leontaritis K., Mansoori G. (1988) Asphaltene Deposition: A Survey of Field Experiences and Research Approaches, J. Petrol. Sci. Eng. 1, 229-239.

Leontaritis K.J., Amaefile J.O., Charles R.E. (1992) A Systematic Approach for the Prevention and Treatment of Formation Damage Caused by Asphaltene Deposition, SPE International Symposium on Formation Damage Control, Lafayette, Louisiana, February 26-27.

Minssieux L. (1997) Core Damage from Crude Asphaltene Deposition, SPE International Symposium on Oilfield Chemistry, Houston, Texas, February 18-21.

Nghiem L.X., Kohse B.F., Farouq A.S.M., Doan Q. (2000) Asphaltene precipitation: modeling and compositional simulation, SPE Asia Pacific Conference on Integrated Modeling for Asset Management, Yokohama, Japan, April 25-26.

Novosad Z., Costain T.G. (1990) Experimental and Modeling Studies of Asphaltene Equilibria for a Reservoir under $\mathrm{CO}_{2}$ injection, 65th SPE Annual Technical Conference and Exhibition, New Orleans, LA, September 23-28.

Papadimitriou N.I., Romanos G.E., Charalambopoulou G.Ch., Kainourgiakis M.E., Katsaros F.K., Stubos A.K. (2007) Experimental investigation of asphaltene deposition mechanism during oil flow in core samples, J. Petrol. Sci. Eng. 57, 281-293.
Rassamdana H., Dabir B., Nematy M., Farhani M., Sahimi M. (1996) Asphalt Flocculation and Deposition: I. The Onset of Precipitation, AICHE J. 42, 1, 10-21.

Rassamdana H., Sahimi M. (1996) Asphalt Flocculation and Deposition: II. Formation and Growth of Fractal Aggregates, AICHE J. 42, 12, 3318-3332.

Sim S.S.K., Takabayashi K., Okatsu K., Fisher D. (2005) Asphaltene-Induced Formation Damage: effect of Asphaltene Particle size and core permeability, SPE Annual Technical Conference, Dallas, Texas, USA, October 9-12.

Srivastava R.K., Huang S.S., Mingzhe D. (1999) Asphaltene Deposition during $\mathrm{CO}_{2}$ Flooding, SPE Prod. Facil. 14, 4, 235-245.

Standing M.B., Katz D.L. (1942) Density of Natural Gases, Trans. AIME. 146, 140-149.

Takahashi S., Yoshihisa H., Takahishi Sh., Yazawa N., Sarma H. (2003) Characteristic and Impact of Asphaltene Precipitation during $\mathrm{CO}_{2}$ Injection in Sandstone and Carbonate Cores: An Investigative Analysis through Laboratory Tests and Compositional Simulations, SPE International Improved Oil Recovery Conference, Kuala Lumpur, Malaysia, October 20-21.

Wang S., Civan F. (2005) Modeling Formation Damage by Asphaltene Deposition during Primary Oil Recovery, J. Energ. Resour.-ASME 127, 310-317. or distributed for profit or commercial advantage and that copies bear this notice and the full citation on the first page. Copyrights for components of this work owned by others than IFP Energies nouvelles must be honored. Abstracting with credit is permitted. To copy otherwise, to republish, to post on servers, or to redistribute to lists, requires prior specific permission and/or a fee: Request permission from Information Mission, IFP Energies nouvelles, fax. +33147527096, or revueogst@ifpen.fr. 